\title{
Metaphor and narrative
}

\author{
Marina Grishakova \\ Department of Comparative Literature, University of Tartu, \\ Ülikooli 17, 50090 Tartu, Estonia \\ e-mail: marina2@ut.ee
}

\begin{abstract}
The paper examines linguistic, cognitive, communicative approaches to metaphor and its functioning in the narrative text. Special attention is paid to the problem of iconicity and the Wittgensteinian notion of "aspect seeing" as relevant to the metaphor studies. It is shown that the extended understanding of metaphor as "trope" or "figure" in the post-structuralist literary theory allows to see metaphor as a textual "interpretation machine". In the process of interaction of narrative and figurative patterns, metaphor functions as a means of perspectivization, i.e. representation of consciousness. In the literary text, perspective changes permanently and the subsequent configurations have an impact on the previous ones: there occurs a permanent "feedback" and correlation.
\end{abstract}

For Viktor Shklovsky, metaphor was a device of "making strange" or "defamiliarization" (ostranenie) to be unfolded into the plot (sjužet). For example, plots of certain erotic tales or Boccaccio's novellas are erotic metaphors unfolded (Shklovsky 1929: 19-20, 69). Shklovsky's thesis may be properly understood in the context of avant-garde, especially futurist poetics with its priority of the "self-sufficient word" (samovitoe slovo) and linguistic experimentation: a sound combination or the realization of metaphor define the logic of textual unfolding (see Hansen-Löve 2000: 92-164). In his book Theory of Prose, Shklovsky expresses a typically futurist opinion: "the form creates the content for itself" (Shklovsky 1929: 35). Shklovsky's approach may be classified as linguistic reduction, i.e. projection of the linguistic principles on to the text structure. The linguistic reduction is also obvious in Roman Jakobson's opposition of metaphor and metonymy (Jakobson 1971: 239-259) and in the literary analyses influenced by 
the Jakobsonian distinction: "[...] the study of tropes and figures [...] becomes a mere extension of grammatical models, a particular subset of syntactical relations" (de Man 1979: 6). For Jakobson, metaphor and metonymy are primarily a manifestation of the paradigmatic and syntagmatic principles in speech. He bases the distinction between the two rhetorical figures on the linguistic principles of selection and combination, substitution and contexture. As D. Lodge justly observes, "contexture' is not an optional operation in quite the same way as 'substitution' — it is, rather, a law of language" (Lodge 1997: 76). Yet "deletion", suggested by Lodge instead of "contexture", is still problematic since it supposes the pre-existence of the "literal", non-metonymical sentences ("The keels of the ships crossed the deep sea") to be transformed into the metonymical ones ("The keels crossed the deep"). The Jakobsonian scheme, however, proves to be rather powerful since even Paul de Man who criticizes the linguistic approach to tropes cannot avoid its influence while speaking of the interaction of the metaphorical and metonymical order which organizes the narrative. One of the most consistent linguisticallyoriented literary scholars is Michael Riffaterre:

$[\ldots]$ every single word $[\ldots]$ contains a potential narrative and a potential diegesis [...]; each word is a sememe, a complex system of associated semantic features or semes $[\ldots]$ and these semes may in turn be actualized in the shape of lexical representations, of satellitic words gravitating around [...] the original sememe. The lexical actualizations themselves are organized by syntax $[\ldots]$. These actualizations form what I call a descriptive system $[\ldots]$ a sememe can be seen as an inchoate or future text, and a story as an expanded sememe in which a temporal dimension has been added to spatial syntagms. (Riffaterre 1990: 5)

Along with structural-linguistic and semiotic approaches, certain cognitive theories oppose the traditional Aristotelian substitution and comparison view on metaphor. The interaction theory takes up I. A. Richard's critique of the traditional point of view, which "made metaphor seem to be a verbal matter, a shifting and displacement of words", and his definition of metaphor as "a borrowing between and intercourse of thoughts, a transaction between contexts" (Richards 1965: 94). According to Richards, there are always two thoughts copresent in metaphor. In calling these two halves "the tenor" and "the vehicle", he introduces the transfer process into the notion of metaphor. Following in Richards' footsteps, the interactionists 
criticized the traditional opinion of metaphor as an "ornament" of speech or a "supplement" being used in case the necessary word is absent in language. They regard metaphor as a conceptual shift or "redescription" (in M. Hesse's terms) which has a heuristic value and therefore may function as a dynamic scientific model. I. A. Richards argues that within a single word a metaphorical collision and interaction of two thoughts occur. Likewise, Max Black discloses the interaction of the principal and subsidiary subject in metaphor: "We can say that the principal subject is 'seen through' the metaphorical expression - or, if we prefer, that the principal subject is 'projected upon' the field of the subsidiary subject" (Black 1962: 41). The interaction theory sees metaphor as a predicative structure dependent on the context and speaker's intention. Metaphor involves a simultaneous manifestation of two ideas, interaction of two semantic fields and, as a result, a conceptual shift prompted by the new connotations acquired by the principal subject. Only dead or trivial metaphors are reducible to literal expressions: "Metaphorical statement is not a substitute for a formal comparison or any other literal statement, but has its own distinctive capacities and achievements" (Black 1962: 37). The cognitive approach has been further developed by George Lakoff (Lakoff, Johnson 1980) for whom metaphor is a cognitive schema which grounds the abstract target domain within the specific basis of the source domain and reflects the space- and world-orientations of the cognitive subject. Yet Lakoff deals mostly with conventional ("dead") metaphors where the similarity and almost identity of the "source" and the "vehicle" are already fixed in language. New meanings are generated by the process of logical unfolding of the cognitive schemata as their natural "entailments". Lakoff's treatment of metaphor implies that metaphoric cognitive schemata may be developed into narratives that govern our social life:

Metaphors may create realities for us, especially social realities. A metaphor may thus be a guide for future action. Such actions will, of course, fit the metaphor. This will, in turn, reinforce the power of the metaphor to make experience coherent. In this sense metaphors can be self-fulfilling prophecies.

For example, faced with the energy crisis, President Carter declared 'the moral equivalent of war'. The WAR metaphor generated a network of entailments. There was an 'enemy', a 'threat to national security', which required 'setting targets', 'reorganizing priorities', 'establishing a new chain of command', 'plotting new strategy', 'gathering intelligence', 'marshalling forces', 'imposing sanctions', 'calling for sacrifices', and on and on. (Lakoff, Johnson 1980: 156) 
According to the conceptual integration theory, a recent outcome of interactionism enriched by Lakoff's elaborations, metaphor is a process of blending of two conceptual spaces. Blending is regarded as a topological operation which is guided by definite generic schemata and involves selective projection and fusion of two spaces. As a result a new space emerges with its own structure: the output is not equal to the sum of the inputs (Fauconnier, Turner 1998, 2000). T. Veale ${ }^{1}$ draws a straight analogy between the metaphorical blending and the narrative blending of conceptual spaces. He examines the cinematic narrative from this point of view, e.g., "Star Wars" as blending of the Arthurian sagas and several cinematic narratives with science fiction; "Forrest Gump" as grounding of Voltaire's "Candide"-type story in American history, etc. Veale's computer-based approach retains only a quantitative difference between metaphor as a restricted two-space blending and the narrative as a multi-space blending.

The cognitive approach focuses on metaphor's capacity to "redescribe" reality. As Paul Ricoeur argues, the mimetic function of the narrative is analogous to the metaphoric reference. Although the former is related to the experience of time and the latter operates in the sphere of perception, emotion and evaluation, both re-figure the pretextual cognitive experience. Likewise, M. Black supposes that a "system of associated implications" or "commonplaces" is essential for the rapid and effective activation of metaphor in consciousness: "[...] the important thing for the metaphor's effectiveness is not that the commonplaces shall be true, but that they should be readily and freely evoked" (Black 1962: 40). Paul Ricoeur sees a common cognitive grounds for metaphor and the narrative: metaphor is a new predicative relation, the narrative is a new relation of events schematized by creative imagination (Ricoeur 2000: 7-10). To summarize, the cognitive view on the relations of metaphor and the narrative involves conceptual reduction: it subordinates both metaphor and the narrative to certain cognitive schemata as the linguistic approach subordinates them to certain linguistic principles.

Finally, the communicatively oriented approaches subordinate metaphor and the narrative to a certain communicative teleology. Thus, J. Searle differentiates the language-meaning from the utterermeaning: it is an utterer-meaning imposed on a literal meaning which

\footnotetext{
${ }^{1}$ Veale, Tony 1996. Creativity as pastiche: A computational treatment of metaphoric blends with special regard to cinematic "borrowing". http// www.compapp.dcu.ie/ $\sim$ tonyv/Pastiche/Pastiche.html.
} 
makes a metaphor (Searle 1979). The rhetorical value of metaphor is reduced to its power of persuasion. Richard Moran in his article "Metaphor, image, and force", referring to D. Davidson's paper "What metaphors mean" and W. Booth's "Metaphor as rhetoric: The problem of evaluation" (both in the collection On Metaphor of 1979), suggests considering metaphor in terms of its effect. He attempts to unify developments of interactionism with the speech-act theory. Moran argues that a distinction should be made between the two dimensions of metaphor: its "content" or "initiating beliefs" together with their further implications, and its "framing effect", i.e. framing one thing in terms of another or "the adoption of the perspective". Citing Booth ("The speaker has performed a task by yoking what the hearer had not yoked before, and the hearer simply cannot resist joining him [...]", Moran 1989: 91) and Davidson ("Joke or dream or metaphor can, like a picture or a bump on the head, make us appreciate some fact - but not by standing for, or expressing, the fact" — Moran 1989: 95), R. Moran observes that the framing-effect is responsible for this "compulsion and involuntary complicity" or the "force" of a good metaphor: "but in such cases what is forced, or can't be undone, is not a believing of what is asserted". "It is quite generally true for both philosophy and literature that much of what they aim at is not on the level of specifically altered beliefs but rather such things as changes in the associations and comparisons one makes, differences in the vivid or 'felt' appreciation of something already known, or changes in one's habits of attention and sense of the important and the trifling" (Moran 1989: 100). What is interesting in R. Moran's paper, is an attempt to explain imagistic capacity of metaphor by the framing-effect "that functions cognitively in a manner which is importantly similar to that of an image" (Moran 1989: 112). It means there is no code to determine in advance which features will make part of the comparison. However, the metaphoric juxtaposition of two things is "directional": one component is the "filter" or "subsidiary subject", the other the "principal subject". Therefore it differs from the pictorial juxtaposition where beholder's attention is not strictly controlled or directed. Nevertheless, we would add, as painting always contains some interpretive signs pointing at the relations of things depicted, so the "live" figure of speech always leaves some freedom for the interpretation of its components. Thus, the "pictorial" analogy may be stimulating in the understanding of figurative speech.

The imagistic capacity of metaphor has been compared to the Wittgensteinian notion of "aspect seeing". Wittgenstein's term "aspect" 
has been discussed as relevant to the study of artistic texts and his notion of "noticing an aspect" as identical to aesthetic perception. In his article "Pictorial meaning, picture thinking, and Wittgenstein's theory of aspects" (Aldrich 1972: 93-103), V. C. Aldrich analyses the phenomenon of "seeing aspects" and draws some conclusions useful for the understanding of "poetic images" and metaphors. He refers to the Wittgensteinian description of "seeing aspects": "It is as if an image came into contact, and for a time remained in contact, with the visual impression" (Aldrich 1972: 97), i. e. "aspect" is a half-percept (half-thought), a half-image. Aldrich supposes that a capacity of an expression to evoke or "conjure up" images depends "on the contextual control on the use" (Aldrich 1972: 94). Following in Wittgenstein's footsteps, he further distinguishes between the "pictorial" (image-exhibiting) and "cognitive" (object-describing) use of expressions, the imaginative and observational mode of awareness, both present in the "plain talk" of non-special conversation and each to be separately developed into the aesthetic and the scientific mode of expression correspondingly (Aldrich 1972: 98-99). M. B. Hester (Hester 1972: 111-123) emphasizes that aspect seeing involves mental activity and imaginative skill and therefore differs from usual passive perception. However, the poetic "seeing as" has to do with the meaning of language, not with a perceivable (visual) form like the Gestalt picture in Wittgenstein's Philosophical Investigations. Hester uses the Wittgensteinian notion of "aspect seeing" in Aldrich's sense of the "image-exhibiting" mode and focuses on the poetic metaphor as "aspect seeing" between the metaphorical subject and the metaphorical predicate: "Both parts of the metaphor retain their distinctiveness, and thus we might say that in a metaphor type-boundaries are transgressed but not obliterated" (Hester 1972: 116-117). Linguistic and textual iconicity, although underrated by M. Hester, is probably the real hidden reason for the analogy between the visual and the poetic "seeing as". Aldrich remarks that the image-exhibiting use of expressions "may be a formulation objectively grounded in, and developing, "experience" of things" (Aldrich 1972: 99). Hester, although more sceptical as regards the straight analogy between the pictorial and verbal "aspect seeing", admits, nevertheless, its efficiency: both visual and metaphorical "seeing as" involve inherent duality, both are there for imaginative notice (an image in contact with a perception), both are tied or controlled by the context, both are "irreducible imaginative accomplishments" (Hester 1972: 119). 
The examination of metaphor as "aspect seeing" helps to estimate its temporality. The "aspect" is provisional: "image" and "thought" remain in contact for a time. The figure of speech is located within a certain historical or individual context, it depends on certain generic conventions or/and, within the text, on a lyric or narrative situation. Only a minor part of poetic tropes enter the "common language". M. Epstein even proposes "the third trope" in addition to metaphor and metonymy - "metabole", where the fusion of the "literal" and "figural" meaning is more close and persistent. Cf.: "Metaphor or comparison is just [...] a flash, of varying brightness but inescapably fading, since it is brought into reality from somewhere outside, to illuminate it for just an instant, in order to inscribe it" (Epstein 1995: 43). An "aspect" is accessible only through a certain configuration of textual elements. It belongs not to the formal textual characteristics but to its elusive "content": it is an image or a quality of the "viewed" as experienced by the "viewer".

Increased attention to the iconic component and imagistic capacity of metaphor, comparative investigation of verbal and visual metaphors, interest in the intersemiotic translation open a new perspective in the metaphor studies:

In shifting from one semiotic system to another, a dead metaphor becomes an inventive one anew [...]. Investigation of the visual metaphor [...] have shown how a worn-out expression like /flexible/ (used to indicate openness of mind, lack of prejudice in decision making, sticking-to the facts) can reclaim a certain freshness when, instead of being uttered verbally, it is translated visually through the representation of a flexible object. (Eco 1983: 255)

On the other side, a remarkable development in the metaphor studies is defined by the extended understanding of metaphor as "figure" or "trope" in general and awareness that its nature is supralinguistic: "[...] metaphor is not a linguistic unit but a text-semantic pattern, and semantic patterns in texts cannot be identified with units of syntax" (Hrushovski 1984: 7). The Jakobsonian definition already ranks metaphor as a generic figure: "In the Jakobsonian "reworking" of the rhetorical heritage, metaphor and metonymy are kinds of super-figures, headings under which other things can be grouped together[...]" (Metz 1983: 169). In the poststructuralist literary analyses metaphor acquires a new status of "figure" or "trope" and works as the textual machine of interpretation. As it seems, the structuralist Todorov falls into contradiction while basing his definition of "figure" upon the 
linguistic model and at the same time describing it as a semantic entity which gives to the text its "form of substance". Thus, "l'essence est absent, la présence est inessentielle" is, according to Todorov, Henry James' master figure which organizes his works both semantically and syntactically, arranges their composition and points of view. It restructures the hierarchy of the linguistic levels and assumes a unique textual form (Todorov 1971: 250). Further extension of the notion of "figure" occurs in J. Hillis Miller's literary analyses. J. Hillis Miller focuses on the recurrent and repetitive patterns (tropes) in fiction and their interaction with narrative lines. For P. de Man, metaphor is a deceptive, mystifying semantic unity being permanently reconstructed and deconstructed in the grammatical networks and finally turned back upon itself as the basic metaphor of reading/writing.

In other words, text is seen as a process: chains of events, segments of description and commentary are permanently re-shaped by interpretation. F. Kermode argues that narrative "may be crudely represented as a dialogue between story and interpretation. This dialogue begins when the author puts pen to paper and it continues through every reading that is not merely submissive". Therefore all narrative

has something in common with the continuous modification of text that takes place in a psychoanalytical process [...] we may like to think, for our purposes, of narrative as the product of two intertwined processes, the presentation of a fable and its progressive interpretation (which of course alters it). (Kermode 1980: 86).

The work of interpretation proceeds not from the superior point of view but from within textuality itself. The text is not an embodiment of certain linguistic or conceptual schemata or principles: the principles themselves are created and transfigured by the double process of narrative production as described by Kermode. In the narrative text, figurative patterns, which fulfil the work of interpretation are guided by the narrative mode (point of view, distance, perspective). The narrative mode mediates between the discourse and the story: it both controls figurative patterns and is controlled and altered by them. As far as the fabula or the story is not an invariant prior to different variants of syuzhet, but a post-factum "mental construction that the reader derives from the syuzhet" (the discourse) (Brooks 1984: 11), the narrative mode controls the reconstruction of the story from the discourse and the interpretative arrangement of narrative levels. Thus, 
the narrative mode plays a mediatory role in the process of textual interpretation (modification) resulting from interaction and convergence of narrative and figurative patterns, i.e. from a correlation between the elements of the story and the discourse, the "world" and the "text".

Due to the correlation of the narrative and figurative patterns metaphor can be seen as a way of perspectivization, i.e. a manifestation of a point of view or a representation of individual consciousness. Compound or mixed metaphor (figure) serves the convergence and mutual infiltration of different points of view ("frames of reference" in B. Hrushovski's terms) or different consciousnesses. Thus, in E. Tarle's example cited by B. Uspenskij (Uspenskij 1970: 33) the change of distance is accompanied by the change of perspective achieved by the shift from the metaphorical to the literal language: Parisian newspapers call Napoleon as he is approaching Paris correspondingly "the Corsican monster", "the cannibal", "the usurper", "Bonaparte", "Napoleon", and, finally "His Majesty". B. Gasparov in his analysis of O. Mandelshtam's "Verses about an Unknown Soldier" demonstrates how the motif of the pilot's death in air, extremely significant in the context of the early 20th century culture, is seen in different perspectives as the author's own anticipation of a future catastrophe (Gasparov 1994: 214-223). The story is interpreted in the perspectives of the Apocalypse, romantic poetry and popular cosmology: the Apocalypse of the First World War, hopelessness and tragic beauty of the romantic outcast's solitary death, death as the overcoming of human "time-lag" (in comparison with the speed of light).

By this means, a distinction should be made between the "point of view" and the "perspective". The point of view is a restriction of the "field of vision", a selection of the initial "frames" (cf. Henry James" "the novelist is a particular window" — Miller 1962: 65). The adoption of the perspective is an interpretative operation, which brings about an extension of the field of vision.

In introducing the notions of "slant" and "filter", Seymour Chatman makes an attempt to differentiate a conscious choice and a mere mediating perception or, otherwise, the "narration" (as "knowing" and "telling") and "focalization" (as "seeing"). The "slant" amounts to "the narrator's attitudes and other mental nuances appropriate to the report function of discourse", to "the psychological, sociological, and ideological ramifications of the narrator's attitudes, which may range from neutral to highly charged", the "filter" embraces "the much 
wider range of mental activity experienced by characters in the story world - perceptions, cognitions, attitudes, emotions, memories, fantasies, and the like". Thus, the "slant" "delimits the mental activity on this side of the discourse-story barrier" whereas the "filter" is "a good term for capturing something of the mediating function of a character's consciousness [...] as events are experienced within the story world" since it "catches the nuance of the choice made by the implied author" (Chatman 1990: 143-144). Chatman's classification proceeds from a strict "distribution of labour" between the narrator who "tells" the story and the character who only "sees" it: as soon as a character starts to "tell", he at once turns into a narrator, and, vice versa, if the narrator limits himself by the passive perception, he does so in a character's capacity within the fictional world. There is a confusion of narrative roles which belong to the story and discourse positions in Chatman's argument. The narrator is involved in the "emplotment", i.e. "goal-oriented and forward moving organization of narrative constituents" (Prince 1987: 72): his narrative role is more or less persistent, at least in a definite textual segment. The discourse position is much more unstable and changeable even within a single sentence (cf. Benveniste's classical analysis of the "I", the subject of speech, as a linguistic construction). If the terms "slant" and "filter" are identical to the roles of the narrator and the character, they just refer to the usual hierarchy of narrative levels: the "distribution of labour" is obvious. Yet it seems that Chatman attempts to combine the narrative roles with discourse positions and operations. It would probably be more fruitful to examine the difference between a conscious selection and mere perception on the level of discourse to see what forms it assumes and what impact it has on the narrative roles.

On the level of discourse manifestation, the perspective is a figurative way of "showing" one thing by means of another thing, e.g., in painting, showing distance by means of color or size relations. It involves a framing effect, i.e. a significant correlation or configuration of heterogeneous intratextual or intertextual elements. Let us take the passage from D. Lodge's "Changing Places" used by Mieke Bal as an example of the "interpretative" focalization:

In the sky the planes look very small. On the runways they look very big. Therefore close up they should look even bigger - but in fact they don't. His own plane, for instance, just outside the window of the assembly lounge, 
doesn't look quite big enough for all people who are going to get into it. (Bal 1991: 134)

As Mieke Bal observes, "it is Swallow's view of the airplanes rather than the airplanes themselves which almost completely constitutes the object presented" (Bal 1991: 135). Nevertheless, the description is built upon the realistic remarks on the relative size of planes. It is an insistent repetition of size-designations ("small", "very big", "even bigger", "not big enough for all people who", etc.) that evokes the image of Swallow's "British" sensitivity and his concern with his own plane's reliability and acquires the metaphorical meaning as a manifestation of the novel's general bi-polarity, i.e. the opposition of America ("big") and Britain ("small").

The syntactic-semantic configurations, as shown by Vinogradov in his analysis of The Queen of Spades, are able to acquire a symbolical meaning and to serve as a figurative interpretation of the events or objects described and introduction of an individual angle of vision. Lizaveta Ivanovna's impatient waiting is made manifest by the repetition of identical syntactic constructions and permanent time counting. The latter appears in the auctorial narration after the first Germann's letter has been received by Lizaveta Ivanovna: "na drugoi den", "tri dnja posle togo", "Lizaveta Ivanovna kazhdyi den' poluchala ot nego pis'ma" (Vinogradov 1980: 212). Poor Lizaveta Ivanovna is a passive character totally dependent on the countess' power and Germann's sinister game. Emotion is the main expression of her "narrative activity". Nevertheless, it is precisely her emotion stirred up by the fashionable romantic stereotypes that permits Germann to get into the house. Thus, Lizaveta Ivanovna's waiting introduces a perspective of the romantic secret story: she does not just wait for Germann, she is waiting for a solution of his secret and is sacrificed to this secret, as it happens to Romantic heroine. Within the frame of Romantic interpretation, the protagonist is either a metaphorical "savior" or a "criminal", a Mephistopheles or a Napoleon. Germann's agitation, fervour and avarice are made manifest by the repetition of the conjunctions and the inversion of the adverbs as compared to their "neutral" location in the Russian sentence: "On stavil kartu za kartoi, gnul ugly reshitel'no, vyigryval besprestanno, i zagrebal $k$ sebe zoloto, i klal assignacii v karman" (Vinogradov 1980: 224). Strictly speaking, is not only the narrator's or only Germann's point of view what is presented: the perspective of the daemonic game of Fatum unifies the external evaluative descrip- 
tion of Germann's resolute, quick, almost automatic action and the implied stream of his unconscious passions. Certain configurations of motifs metonymically or metaphorically related to a theme or a higherorder motif are also manifestations of a perspective. For instance, in Nabokov's "Mary" the main axis is set by the parallel between shooting a film in the protagonist's former "shadow life" and the house building in his new "real life". The first: "the lazy workmen walking easily and nonchalantly like blue-clad angels from plank to plank high above", and a mob of extras "acting in total ignorance of what the film is about" (Nabokov 1970: 21). The second: "The figures of the workmen on the frame showed blue against the morning sky. One was walking along the ridge-piece, as light and free as though he were about to fly away [...]. This lazy, regular process had a curiously calming effect [...]" (Nabokov 1970: 113-114). The metaphorical motives of easiness, nonchalance, freedom, flight, blue colour, height, sky create the image of an escape and aspiration for the otherworld fusing the horizons of the auctorial narrator and the character. The whole textual segments may be metonymically or metaphorically juxtaposed to each other, e.g. a "metonymical description" or landscape as part of character's consciousness, as shown by S. Rimmon-Kenan (1983: 63-70). Another example is the often-cited fair episode in Madame Bovary. The critics repeatedly indicated the contrast of high romantic feelings and low agricultural details ironically juxtaposed in the scene that gave the idea of montage to Eisenstein. But the contrasting parts are also interrelated by metaphorical similarity: Rodolphe "emancipates" Emma to convince her that marriage is not an obstacle for love of chosen souls. Likewise, the politics "emancipate" the people convincing them to strive for further agricultural achievements. In both cases the emancipation involves corruption: the romantic phraseology conceals the sexual desire in the first case and the work of political machinery in the second case.

In Nabokov's Pale Fire, old John Shade fails to see his house from Lake Road although he has seen it many times in his boyhood when his eyesight has been keener: "Maybe some quirk in space // Has caused a fold or furrow to displace // The fragile vista, the frame house between // Goldsworth and Wordsmith on its square of green" (Nabokov 1991: 30). Kinbote the commentator who rents Judge Goldsworth's house contests the exactitude of the Shadean topography: 
In seeming to suggest a midway situation between the two places, our poet is less concerned with spatial exactitude than with a witty exchange of syllables invoking the two masters of the heroic couplet, between whom he embodies his own muse. Actually, the "frame house on its square of green" was five miles west of the Wordsmith campus but only fifty yards or so distant from my east windows. (Nabokov 1991: 68)

We cannot fully rely on Kinbote's "real" commentary since he is concerned with reminding to the reader of his being the poet's confidential friend close to him both spiritually and topographically. "Between" does not necessarily mean "a midway situation" and Wordsworth is not the "master of the heroic couplet". Shade's poor sight correlates with Kinbote's psychological unreliability. As a result, a moving house emerges, the house which is sometimes visible, sometimes invisible, situated either in the real space between Goldsworth's house and the Wordsmith campus or in the continued imaginary space, an optical metaphor of miraculous poetical imagination which balances on the border between involuntary blindness and conscious self-deception.

In the literary text, as distinct from the historical or philosophical one, the perspective is changing constantly and a new configuration has a retroactive effect on the previous configurations: there is a permanent "feedback". Trope as a means of perspectivization is comparable to the dual- or multiple-voice effect: it allows "to draw non-standard meaning lines" (Hintikka, Sandu 1994: 160) without a clear identification of the speaker.

\section{References}

Aldrich, Virgil C. 1972. Pictorial meaning, picture thinking, and Wittgenstein's theory of aspects. In: Shibles, W. (ed.), Essays on Metaphor. Whitewater: Language Press, 93-103.

Bal, Mieke 1991. On Story-Telling. Essays in Narratology. California: Sonoma.

Black, Max 1962. Models and Metaphor: Studies in Language and Philosophy. Ithaca: Cornell University Press.

Brooks, Peter 1984. Reading for the Plot: Design and Intention in Narrative. New York: Knopf Press.

Chatman, Seymour 1990. Coming to Terms: The Rhetoric of Narrative in Fiction and Film. Ithaca: Cornell University Press.

Eco, Umberto 1983. The scandal of metaphor. Poetics Today 4(2): 217-258. 
Epstein, Mikhail 1995. After the Future: The Paradoxes of Postmodernism and Contemporary Russian Culture. Amherst: The University of Massachusetts Press.

Fauconnier, Gilles; Turner, Mark 1998. Conceptual integration networks. Cognitive Science 22(2): 133-187.

Fauconnier, Gilles; Turner, Mark 1999. A mechanism of creativity. Poetics Today 20(3): 397-418.

Gasparov, Boris 1994 = Гаспаров, Борис 1994. Литературные лейтмотивы. Москва: Наука.

Hansen-Löve, Aage A. 2001 = Ханзен-Лёве, Оге A. 2001. Русский формализи: Методологическая реконструкиия развития на основе приниипа остранения. Москва: Языки русской культуры.

Hester, Marcus B. 1972. Metaphor and aspect seeing. In: Shibles, W. (ed.), Essays on Metaphor. Whitewater: Language Press, 111-113.

Hintikka, Jaakko; Sandu, Gabriel 1994. Metaphor and other kinds of nonliteral meaning. In: Hintikka, Jaakko (ed.), Aspects of Metaphor. Dordrecht: Kluwer Academic Publishers, 151-188.

Hrushovski, Benjamin 1984. Poetic metaphor and frames of reference. Poetics Today 5(1): 5-44.

Jakobson, Roman 1971. Two aspects of language and two types of aphasic disturbances. In: Jakobson, Roman, Selected Writings, vol. 2. Word and Language. The Hague: Mouton Publishers, 239-259.

Kermode, Frank 1980. Secrets and narrative sequence. Critical Inquiry 7(1): 83101.

Lakoff, George; Johnson, Mark 1980. Metaphors We Live By. Chicago: The University of Chicago Press.

Lodge, David 1977. The Modes of Modern Writing: Metaphor, Metonymy, and the Typology of Modern Literature. London: Arnold.

Man, Paul de 1979. Allegories of Reading. New Haven: Yale University Press.

Metz, Christian 1983. Psychoanalysis and Cinema: The Imaginary Signifier. London: Macmillan.

Miller, J. E. (ed.) 1962. Theory of Fiction: Henry James. Lincoln: University of Nebraska Press.

Moran, Richard 1989. Metaphor, image, and force. Critical Inquiry 16: 87-112.

Nabokov, Vladimir 1970. Mary. (Trans. by M. Glenny in collaboration with the author.) New York: McGraw-Hill Book Company.

- 1991. Pale Fire. London: Penguin Books

Prince, Gerald 1987. A Dictionary of Narratology. Lincoln: University of Nebraska Press.

Richards, Ivor 1965 [1936]. The Philosophy of Rhetoric. London: Oxford University Press.

Ricoeur, Paul 2000 = Рикёр, Поль 2000. Время и рассказ. Том 1. Москва: Университетская Книга.

Riffaterre, Michael 1990. Fictional Truth. Baltimore: Johns Hopkins University Press.

Rimmon-Kenan, Shlomith 1983. Narrative Fiction: Contemporary Poetics. London: Methuen. 
Searle, John R. 1979. Expression and Meaning. Cambridge: Cambridge University Press.

Shklovsky, Viktor 1929 = ІІкловский, Виктор 1929. O теории прозы. Москва: Федерация.

Todorov, Tzvetan 1971. Poétique de la prose. Paris: Éditions du Seuil.

Uspenskij, Boris $1970=$ Успенский, Борис 2000. Поэтика композиции. Москва: Искусство.

Vinogradov, Viktor 1980 = Виноградов, Виктор 1980. О языке художественной прозы. Москва: Наука.

\section{Метафора и нарратив}

В статье дается обзор лингвистических, когнитивных и коммуникативных подходов к метафоре и ее функционированию в нарративном тексте. Особое внимание уделяется проблеме иконичности и использованию витгеншттейновского понятия "аспекта" в изучении метафоры. В работе указывается, что расширенное понимание метафоры как "фигуры” или “тропа" в поструктуралистском дискурсе позволяет видеть в метафоре текстовую "машину интерпретации". В процессе взаимодействия нарративных и фигуративных моделей (patterns) метафора является способом перспективизации, т.е. репрезентации сознания. Последующие конфигурации взаимодействуют с предшествующими: в тексте осуществляется постоянная “обратная связь” и корреляция.

\section{Metafoor ja narratiiv}

Artiklis antakse ülevaade lingvistilistest, kognitiivsetest ja kommunikatiivsetest lähenemistest metafoorile ja tema funktsioneerimisest narratiivses tekstis. Erilist tähelepanu pööratakse ikoonilisuse probleemile ja Wittgensteini mõiste "aspekt" kasutamisele metafoori uurimisel. Töös näidatakse, et metafoori kui "figuuri" või "troobi" laiendatud mõistmine postrukturalistlikus diskursuses võimaldab metafooris näha tekstilist "interpretatsiooni masinat". Narratiivsete ja figuratiivsete mudelite (patterns) vastastikuses mõjutusprotsessis on metafoor perspektiivi loomise, st teadvuse representeerimise viisiks. Järgnevad konfiguratsioonid on eelmiste mõjuväljas: tekstis toimub pidev "tagasiside" ja korrelatsioon. 